\title{
ECOLOGICAL RESPONSES OF STREAM ECOSYSTEMS TEN YeARS AFTER DISTURBANCE BY WILDFIRE
}

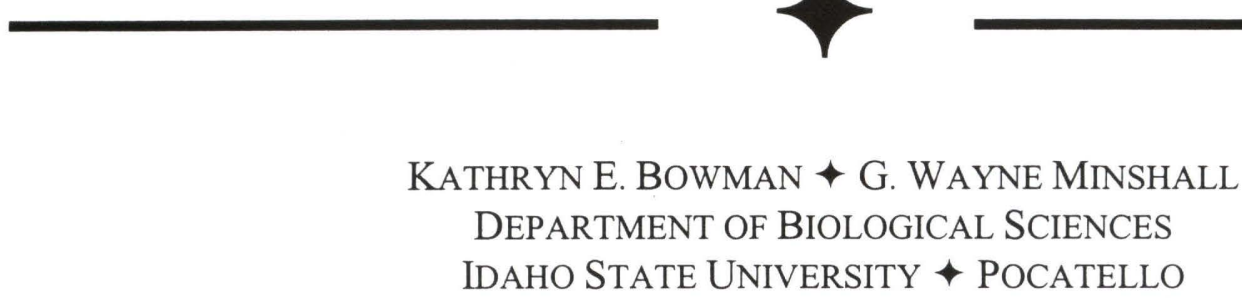

\section{$\uparrow \quad$ SUMMARY}

Wildfire is a major large-scale disturbance that profoundly influences stream ecosystems over broad spatial and temporal scales. Research has focused primarily on short-term effects, with most data collected within the first few months or years following wildfire. We determined the ecological conditions of 13 streams (10 burned, 3 unburned) 10 years after major fires in Yellowstone National Park (YNP), in order to determine the mid-term responses of stream ecosystems to wildfire. Information from this study is critical to the basic understanding of the role of wildfires in the flowing water systems of wilderness areas and national parks. In addition, this information will be helpful in the formulation of future fire policies and resource management approaches in public forests, wilderness areas, and parks and will provide educational and interpretive information to aid the public and its representatives in better understanding the importance of fire in natural ecosystems. Differences among burned streams in chemical properties were related to local geology and not to the effects of fire. Stream habitat measurements indicated that there was more fine sediment in the burned headwater streams compared to the reference streams and that burned mid-size streams were wider and shallower than the comparable sized reference stream. Benthic macroinvertebrate density was higher and percent Ephemeroptera-PlecopteraTrichoptera was lower in the burned streams than in the reference. These changes were accompanied by an increase in the proportion of smaller, more vagile taxa, suggesting a shift in community structure from $\mathrm{K}$ - to $\mathrm{r}$ strategists. However, these differences did not exist for taxa richness or biomass, indicating that metabolic compensation accompanied the change in community structure. Mid-term recovery appears to be delayed in YNP streams as a result of increased precipitation and runoff in recent years. These results indicate that significant changes are still occurring in these streams ten years after the fires; these impacts and trends are expected to be even more apparent when the patterns over the whole ten years are examined.

\section{$\downarrow \quad$ INTRODUCTION}

In 1988 the Greater Yellowstone Ecosystem experienced numerous and extensive wildfires. Thirtytwo percent of the stream systems in Yellowstone National Park, incorporating 20 separate river basins or major sub-basins was burned (Minshall et al. 1989, Minshall and Brock 1991). Minshall and Brock (1991) predicted the short- (immediate), mid- (10-25 years), and long-term (50-300 years) effects of fire on these streams. They reasoned that the mid- and long-term recovery would correspond with revegetation in the burned catchments. Blacktail Deer Creek, in the northcentral part of the Park, was among the most severely burned areas with about $90 \%$ of the catchment burned by intense crown and ground fire (Minshall et al. 1997).

The Cache Creek catchment and Twin Creek, both located in the northeast section of the Park, were two other intensively burned areas, with 60 to $70 \%$ of their catchments being affected. From past studies, we know that the Cache and Twin Creek sites have experienced some of the most drastic changes in channel morphology and physical habitat of the burned streams 
(Minshall et al. 1997). Because of the interconnectedness of streams and their catchments, fires may affect the hydrology, water chemistry, and geomorphology of stream ecosystems (Tiedemann et al. 1979, Minshall et al. 1989). The large-scale disturbance resulting from wildfire affects the biotic portion of the stream by altering the physical structure of the channel and water quality.

The primary goal of this study was to ascertain the status of the streams and biota after 10 years in order to determine the mid-term response and refine hypotheses about the long-term responses of stream ecosystems to disturbance by wildfire. Our study focuses on changes in the chemical constituents of the water, physical habitat conditions, and the structure of the biotic community- both primary producer and consumer portions. Ten burned stream and 3 unburned sites, located in the northern portion of YNP, were examined. Six sites ranging from $1^{\text {st }}$ to $4^{\text {th }}$ order (Strahler 1952) size stream reaches were located in the Cache Creek catchment. Other burned sites included Twin Creek (opposite the mouth of Cache Creek) and Blacktail Deer Creek (west face, east face, and mainstem). Nearby unburned streams, Amphitheater, Pebble, and Rose Creeks, served to estimate reference conditions (Table 1). Information obtained from this study is important in understanding the role of wildfires in the spatial structure and function of streams in Yellowstone National Park. In addition, this data will be combined with previous data collected to determine the extended temporal perspective of wildfire impacts.

\begin{tabular}{|c|c|c|c|c|c|c|}
\hline Stream & Status & Order & $\begin{array}{c}\text { Discharge } \\
\left(\mathrm{m}^{3} / \mathrm{s}\right)\end{array}$ & $\begin{array}{l}\text { Slope } \\
(\%)\end{array}$ & Longitude & Latitude \\
\hline Cache Creek (Upper) & B & 1 & 0.002 & 10.4 & $110^{\circ} 03^{\prime} \mathrm{E}$ & $44^{\circ} 51^{\prime} \mathrm{N}$ \\
\hline E.F. Blacktail Deer & B & 1 & 0.025 & 5.5 & $110^{\circ} 35^{\prime} \mathrm{E}$ & $44^{\circ} 53^{\prime} \mathrm{N}$ \\
\hline Twin Creek & B & 1 & 0.047 & 8.3 & $110^{\circ} 10^{\prime} \mathrm{E}$ & $44^{\circ} 48^{\prime} \mathrm{N}$ \\
\hline W.F. Blacktail Deer & B & 1 & 0.081 & 3.5 & $110^{\circ} 35^{\prime} \mathrm{E}$ & $44^{\circ} 53^{\prime} \mathrm{N}$ \\
\hline Cache Creek (Upper) & B & 2 & 0.017 & 11.1 & $110^{\circ} 05^{\prime} \mathrm{E}$ & $44^{\circ} 49^{\prime} \mathrm{N}$ \\
\hline Cache Creek (Lower) & B & 2 & 0.021 & 5.9 & $110^{\circ} 05^{\prime} \mathrm{E}$ & $44^{\circ} 50^{\prime} \mathrm{N}$ \\
\hline Main Blacktail Deer & B & 2 & 0.222 & 2.6 & $110^{\circ} 35^{\prime} \mathrm{E}$ & $44^{\circ} 53^{\prime} \mathrm{N}$ \\
\hline Rose Creek & $\mathrm{u}$ & 2 & 0.081 & 7.1 & $110^{\circ} 13^{\prime} \mathrm{E}$ & $44^{\circ} 54^{\prime} \mathrm{N}$ \\
\hline Amphitheater Creek & $\mathrm{U}$ & 2 & 0.210 & 3.0 & $110^{\circ} 04^{\prime} \mathrm{E}$ & $44^{\circ} 56^{\prime} \mathrm{N}$ \\
\hline S.F. Cache Creek & B & 3 & 0.308 & 2.3 & $110^{\circ} 04^{\prime} \mathrm{E}$ & $44^{\circ} 50^{\prime} \mathrm{N}$ \\
\hline Cache Creek & B & 3 & 0.790 & 1.3 & $110^{\circ} 04^{\prime} \mathrm{E}$ & $44^{\circ} 51^{\prime} \mathrm{N}$ \\
\hline Pethic Creck & $\mathrm{u}$ & 3 & 0.727 & 2.3 & $110^{\circ} 07 \mathrm{E}$ & $44^{\circ} 56^{\prime} \mathrm{N}$ \\
\hline Cache Creek & B & 4 & 0.900 & 0.1 & $110^{\circ} 05^{\prime} \mathrm{E}$ & $44^{\circ} 50^{\circ} \mathrm{N}$ \\
\hline
\end{tabular}

\section{METHODS}

The methods were consistent with those used in our previous studies of wildfire and wilderness streams, are relatively routine in stream ecology, and are described in detail in standard reference sources (Weber 1973, Lind 1979, Merritt and Cummins 1996, American Public Health Association 1992). All streams were sampled August 4 to 9, 1998.

Chemical measurements were $\mathrm{pH}$, specific conductance, alkalinity, and hardness. Specific conductance $\left(\mu \mathrm{S} / \mathrm{cm} @ 25^{\circ} \mathrm{C}\right)$ and $\mathrm{pH}$ were measured in the field with Orion meters. Water samples were collected and later analyzed in the laboratory for alkalinity $\left(\mathrm{mg} \mathrm{CaCO}_{3} / 1\right)$ and hardness $\left(\mathrm{mg} \mathrm{CaCO}_{3} / 1\right)$ by methyl-purple and EDTA standard titration methods, respectively (APHA 1992).

Five permanent transects, established at approximately 50-meter intervals in 1988, were sampled to measure changes in channel morphology and riparian conditions over time. Hydraulic gradient was determined with an inclinometer and also a hand level by measuring water surface elevations over several substantial reach lengths to give a good estimate of the mean. Gradient equals rise in stream height divided by the length of the stream reach examined. Stream discharge $\left(\mathrm{m}^{3} / \mathrm{s}\right)$ was calculated at one crosssectional transect by separating the transect into increments and multiplying the velocity by the crosssectional area of the flow of each increment and then summing the increments (Bovee and Milhous 1978). An Ott C-1 current meter was used to determine mean water velocity $(\mathrm{m} / \mathrm{s})$ at 0.6 water depth. Mean substratum size, $\%$ embeddedness, and water depth were measured at 100 locations throughout the channel and along approximately $200 \mathrm{~m}$ of stream reach (Platts 1983). The locations were determined using a previously generated random numbers table.

Benthic algal samples were collected from five riffle/run rocks, one near each transect, using an aerial sampler. A plastic tube was placed over the area of the substratum to be sampled. A neoprene gasket sealed the tube to the substrate and prevented leakage of dislodged material. A known area $\left(3.14 \mathrm{~cm}^{2}\right)$ was brushed using a modified hard-bristled toothbrush and a suction pipette was used to remove the slurry and deposit it on a 0.45 um pre-ashed glass fiber filter. Samples were immediately filtered and frozen with liquid nitrogen (and kept in the dark) to prevent degradation. In the laboratory, algal abundance was calculated by quantifying ash-free dry mass and 
chlorophyll $a$ using standard methods (APHA 1992). Methods used for sampling benthic macroinvertebrates are described in Platts et al. (1983) and Merritt and Cummins (1996). Briefly, five quantitative Surber samples $\left(929 \mathrm{~cm}^{2}\right.$ with a $250 \mu \mathrm{m}$ mesh capture net) were collected from riffle/run habitats and preserved in $10 \%$ formalin. In the laboratory each macroinvertebrate sample was hand-sorted and identified to the lowest feasible taxonomic level using standard identification keys (Merritt and Cummins 1996, and others). After identification, the macroinvertebrates were dried at $50^{\circ}$ $\mathrm{C}$ and weighed with an electrobalance to determine biomass. Benthic macroinvertebrate communities were examined in terms of density, biomass, taxa richness, and Simpson's Index. In addition, percent Ephemeroptera (E), Plecoptera (P), and Trichoptera (T) and percent Diptera were calculated for each stream. Percent EPT is frequently reported because of the sensitivity to anthropogenic disturbance exhibited by members of these groups as a whole. The sorting process separated the macroinvertebrates from the organic matter that occurred in the sample. The leftover organic matter then was dried and ashed to determine standing stock of benthic organic matter $(\mathrm{BOM})$ in the stream.

\section{RESULTS}

Discharge increased as stream order increased (Table 1). Discharge was lowest in Upper Cache 1, $0.002 \mathrm{~m}^{3} / \mathrm{s}$. Discharge at Amphitheater and Rose Creeks, 0.21 and $0.08 \mathrm{~m}^{3} / \mathrm{s}$, was higher than the comparable size burned sites in the Cache Creek basin, 0.017 and $0.021 \mathrm{~m}^{3} / \mathrm{s}$ at Upper and Lower Cache 2, respectively (Table 1). SF Cache 3 had a lower discharge $\left(0.308 \mathrm{~m}^{3} / \mathrm{s}\right)$ than the other $3^{\text {rd }}$ order sites, burned Cache $3\left(0.79 \mathrm{~m}^{3} / \mathrm{s}\right)$ and Cache $4\left(0.9 \mathrm{~m}^{3} / \mathrm{s}\right)$ and unburned Pebble $\left(0.73 \mathrm{~m}^{3} / \mathrm{s}\right)$ had the highest discharge (Table 1).
Alkalinity ranged from $38-52 \mathrm{mg} \mathrm{CaCO} / 1$ in the first order streams and $27-91 \mathrm{mg} \mathrm{CaCO} / 1$ in the second and third order streams (Table 2). Hardness ranged from $49-67 \mathrm{mg} \mathrm{CaCO}_{3} / 1$ in the first order, $38-91 \mathrm{mg} \mathrm{CaCO} / 1$ in the second, and $42-127 \mathrm{mg} \mathrm{CaCO}_{3} / 1$ in the third order streams (Table 2). Specific conductance ranged from $92-142 \mu \mathrm{S} / \mathrm{cm}$ in the first order, $51-172 \mu \mathrm{S} / \mathrm{cm}$ in the second order, and $62-188 \mu \mathrm{S} / \mathrm{cm}$ in the third order streams (Table 2). The measured ranges are consistent with those noted by Robinson and Minshall (1996). The observed differences are most likely due to conditions in the catchments (local geology) and not to the effects of fire, since no consistent pattern existed between burned and unburned streams.

Table 2. Water chemistry measures for the 1998 Yellowstone strearris.

\begin{tabular}{|c|c|c|c|}
\hline Stream & $\begin{array}{c}\text { Alkalinity } \\
\text { (mg CaCO} 3 / L)\end{array}$ & $\begin{array}{c}\text { Hardness } \\
(\mathrm{mg} \mathrm{CaCO} / \mathrm{L})\end{array}$ & $\begin{array}{l}\text { Conductance } \\
\text { (uS } / \mathrm{cm} @ 20^{\circ} \mathrm{C} \text { ) }\end{array}$ \\
\hline Upper Cache 1 & 52 & 49 & 142 \\
\hline EF Blacktail Deer & 45 & 52 & 113 \\
\hline Twin & 51 & 67 & 96 \\
\hline WF Blacktail Deer & 38 & 54 & 92 \\
\hline Upper Cache 2 & 50 & 42 & \\
\hline Lower Cache 2 & 72 & 85 & 172 \\
\hline Main Blacktail Deer & 42 & 79 & 108 \\
\hline Rose & 57 & 91 & 133 \\
\hline Amphitheater & 29 & 38 & 51 \\
\hline SF Cache 3 & 33 & 42 & 85 \\
\hline Cache 3 & 27 & 49 & 62 \\
\hline Pebble & 77 & 127 & 188 \\
\hline Cache 4 & 27 & 30 & 42 \\
\hline
\end{tabular}

Within the Cache Creek basin, mean bankfull width was similar between the burned Upper Cache 2 and unburned Amphitheater Creek; both of these streams were double the value of Lower Cache 2 (Table $3)$. Cache 3 was significantly larger in width than its closest reference stream, Pebble Creek, even though their discharge values were similar, 0.79 and $0.73 \mathrm{~m}^{3} / \mathrm{s}$,

Table 3. Channel substratum, morphology and habitat heterogeneity measures for the 1998 Yellowstone streams. SD=+1 SD from the mean, $C V=c 0 e f f i c i e n t$ of variation.

\begin{tabular}{|c|c|c|c|c|c|c|c|c|c|c|c|c|}
\hline & $\begin{array}{c}\text { Subtrate size } \\
\text { Mean }(\mathrm{cm}) \\
n=100\end{array}$ & SD & CV & $\begin{array}{c}\text { Embeddedness } \\
\text { Mean }(\%) \\
n=100\end{array}$ & SD & CV & $\begin{array}{l}\text { Mean bankfull width } \\
\qquad \begin{array}{c}(m) \\
n=5\end{array}\end{array}$ & SD & CV & $\begin{array}{c}\text { Mean baseflow depth } \\
\text { (cm) } \\
n=100\end{array}$ & SD & CV \\
\hline Upper Cache 1 & 7.10 & 6.33 & 0.89 & 35.52 & 31.83 & 0.90 & 4.82 & 1.83 & 0.38 & 6.52 & 3.57 & 0.55 \\
\hline EF Blacktail Deer & 19.43 & 27.92 & 1.44 & 32.56 & 35.12 & 1.08 & 4.52 & 1.54 & 0.34 & 14.41 & 8.62 & 0.60 \\
\hline Twin & 12.99 & 14.82 & 1.14 & 34.50 & 36.70 & 1.06 & 13.76 & 10.03 & 0.73 & 11.86 & 8.55 & 0.72 \\
\hline WF Blacktail Deer & 21.34 & 22.84 & 1.07 & 40.50 & 35.49 & 0.88 & 5.18 & 2.36 & 0.46 & 21.88 & 13.32 & 0.61 \\
\hline Upper Cache 2 & 8.67 & 6.93 & 0.80 & 31.50 & 33.09 & 1.05 & 13.74 & 6.80 & 0.50 & 10.74 & 6.89 & 0.64 \\
\hline Lower Cache 2 & 15.19 & 12.77 & 0.84 & 30.50 & 28.63 & 0.94 & 5.32 & 1.83 & 0.34 & 10.40 & 7.03 & 0.68 \\
\hline Main Blacktail Deer & 18.38 & 18.45 & 1.00 & 28.75 & 33.61 & 1.17 & 7.46 & 1.46 & 0.20 & 19.91 & 10.86 & 0.55 \\
\hline Rose & 17.22 & 15.61 & 0.91 & 24.75 & 25.86 & 1.04 & 4.85 & 1.01 & 0.21 & 13.70 & 8.05 & 0.59 \\
\hline Amphitheater & 15.10 & 15.67 & 1.04 & 20.00 & 27.16 & 1.36 & 13.37 & 6.03 & 0.45 & 18.07 & 9.11 & 0.50 \\
\hline SF Cache 3 & 19.44 & 10.60 & 0.55 & 18.75 & 25.09 & 1.34 & 20.82 & 2.98 & 0.14 & 16.18 & 9.18 & 0.57 \\
\hline Cache 3 & 18.43 & 13.38 & 0.73 & 26.25 & 29.87 & 1.14 & 66.96 & 8.85 & 0.13 & 18.31 & 14.18 & 0.77 \\
\hline Pebble & 26.59 & 22.87 & 0.86 & 26.75 & 27.22 & 1.02 & 12.10 & 1.75 & 0.14 & 25.85 & 10.40 & 0.40 \\
\hline Cache 4 & 22.79 & 14.38 & 0.63 & 26.25 & 32.28 & 1.23 & 27.97 & 8.79 & 0.31 & 17.53 & 11.44 & 0.65 \\
\hline
\end{tabular}


respectively. The streams in the Blacktail Deer drainage were comparable in mean bankfull width to the Rose and Amphitheater reference sites. Mean baseflow depths ranged from $6.5-3.6 \mathrm{~cm}$ to $21.9-13.3$ $\mathrm{cm}$ in the first order streams, $10.4-7.0 \mathrm{~cm}$ to 19.9 $10.9 \mathrm{~cm}$ in the second order streams and $16.2-9.2 \mathrm{~cm}$ to $25.9-10.4 \mathrm{~cm}$ in the third order streams (Table 3).

Mean substrate size (size measured along the longest axis of the substrate) increased in a downstream direction from Upper Cache $1^{0}$ to Cache $4^{0}$ from $7.1 \mathrm{~cm}$ to $22.8 \mathrm{~cm}$ (Table 3). Mean substrate size in Amphitheater $(15.1 \mathrm{~cm})$ was similar to Lower Cache 2 $(15.2 \mathrm{~cm})$ and double that of Upper Cache 2, but the values were highly variable (Table 3 ). Median substrate sizes, however showed the three streams to be similar in sediment size. Twin Creek and the Blacktail Deer sites mean substrate sizes were not significantly different from any of the reference sites or the Cache sites, due to the large variance.

Percent embeddedness is an indication of the degree of fine sediments (less than $53 \mu \mathrm{m}$ ) present in a stream. Mean substrate embeddedness decreased in a downstream direction from $35.5 \%$ at Upper Cache 1 to $26.3 \%$ at Cache 4 (Table 3 ). This indicates that there is still a lot of fine inorganic sediment present in the tributaries. Mean substrate embeddedness in Amphitheater, $20.0 \%$, was less than mean embeddedness in the comparable-sized burned streams (Table 3). The CVs of the headwater sites were similar to those in Amphitheater Creek. This trend also applied to the other burned sites, the smaller $1^{\text {st }}$ and $2^{\text {nd }}$ order streams had a high percent embeddedness (29-41\%) and were higher than the reference streams but not significantly so, due to the large variance around the mean.

Mean periphyton chlorophyll $a$ was highest in Upper Cache 1 with a value of $16.3-22.6 \mathrm{mg} / \mathrm{m}^{2}$, a value more than $8 \mathrm{x}$ that of any other stream sampled (Figure 1). Upper Cache 1 had two transects that prejudice the high calculated mean. If the values from transects 3 and 5 are excluded, the mean is $0.79+/$ $0.53 \mathrm{mg} / \mathrm{m}^{2}$. Mean values of periphyton chlorophyll a were comparable at the remaining sites. Other than Upper Cache 1, chlorophyll a values were similar to those recorded in Amphitheater Creek. Although Cache 4 had the lowest chlorophyll a value, it had the highest periphyton Ash-Free Dry Matter value $\left(0.03-0.05 \mathrm{~g} / \mathrm{m}^{2}\right)$ (Figure 1). Periphyton AFDM and Benthic Organic Matter values at all burned sites were not significantly different than those recorded in the reference streams (Figure 1). However, mean AFDM was much higher in SF Cache 3 and BOM was higher in WF Blacktail Deer than in any of the other sites (with subsequent high variances that kept the differences from being statistically significant). The only apparent trend in BOM values observed was that the Blacktail Deer sites had higher values than the reference sites and comparable burned sites, probably due to differences in riparian vegetation.
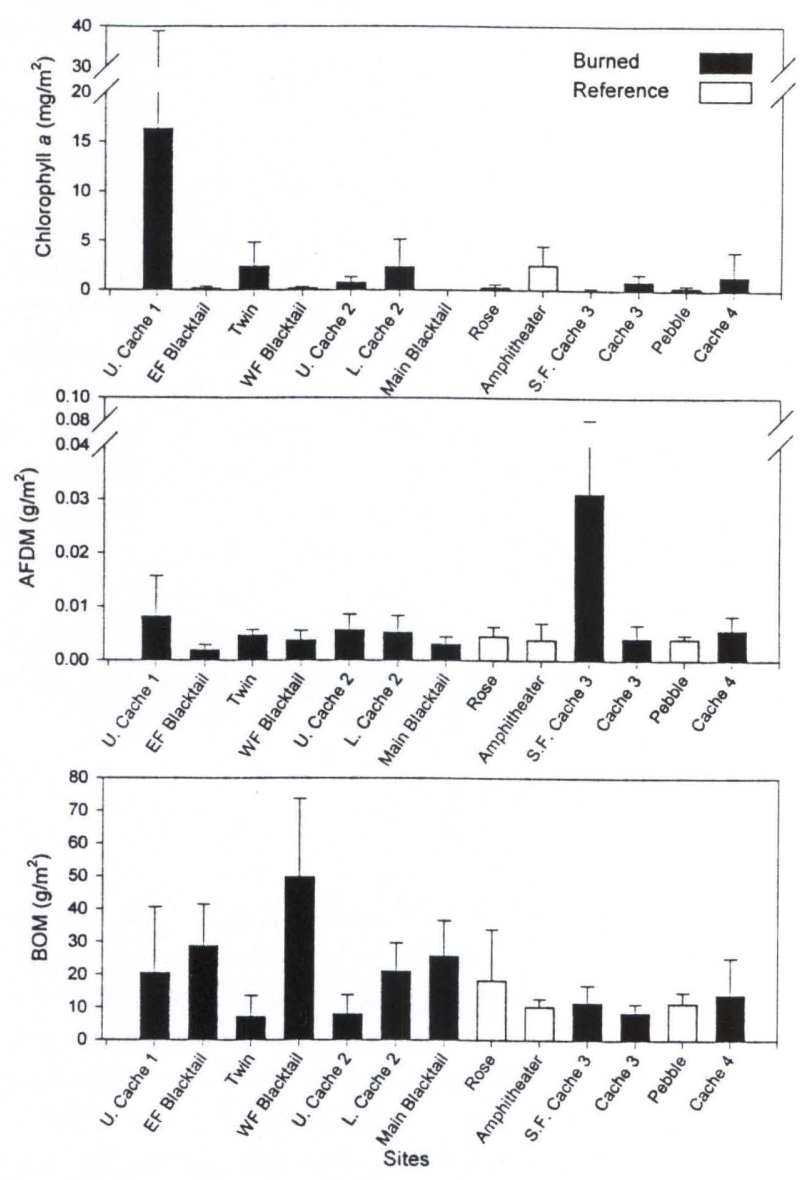

Figure 1. Periphyton chlorophyll a, ash-free dry mass (AFDM). and benthic organic matter from the 1998 sites. Error bars equal $+1-1$ SD from the mean, $n=5$.

Mean benthic macroinvertebrate density (number of individuals per $\mathrm{m}^{2}$ ) was highest in WF Blacktail Deer (which also had the highest BOM values) with over 23,000 individuals $/ \mathrm{m}^{2}$ and lowest in Upper Cache 2 with 3,000 individuals $/ \mathrm{m}^{2}$ (Figure 2). Forty two percent of the benthic macroinvertebrate community in WF Blacktail Deer was Chironomidae which constituted nearly 9,000 individuals $/ \mathrm{m}^{2}$, almost three times the average in the comparable sized Twin and Upper Cache 1. All burned streams except for Upper Cache 2 had higher densities than the reference streams, with 4,000-9,000 individuals/ $\mathrm{m}^{2}$ (Figure 2). Lower Cache 2 and SF Cache were less severely burned (47 \& 39\%, respectively) than any of the other sites. Lower Cache 2 had a higher density than Upper Cache 2 but two the Cache $3^{\text {rd }}$ order sites had similar benthic macroinvertebrate densities. Twin Creek, EF Blacktail 
and Main Blacktail Deer densities were comparable to Upper Cache 1 and Lower Cache 2. Mean macroinvertebrate biomass $\left(\mathrm{mg} / \mathrm{m}^{2}\right)$ values of the burned streams were similar to the respective order reference streams, with the exception of Upper Cache 1, with a mean, $24 \mathrm{mg} / \mathrm{m}^{2}$, that was higher than Amphitheater or Rose Creeks with 10 and $14 \mathrm{mg} / \mathrm{m}^{2}$, respectively (Figure 2 ).
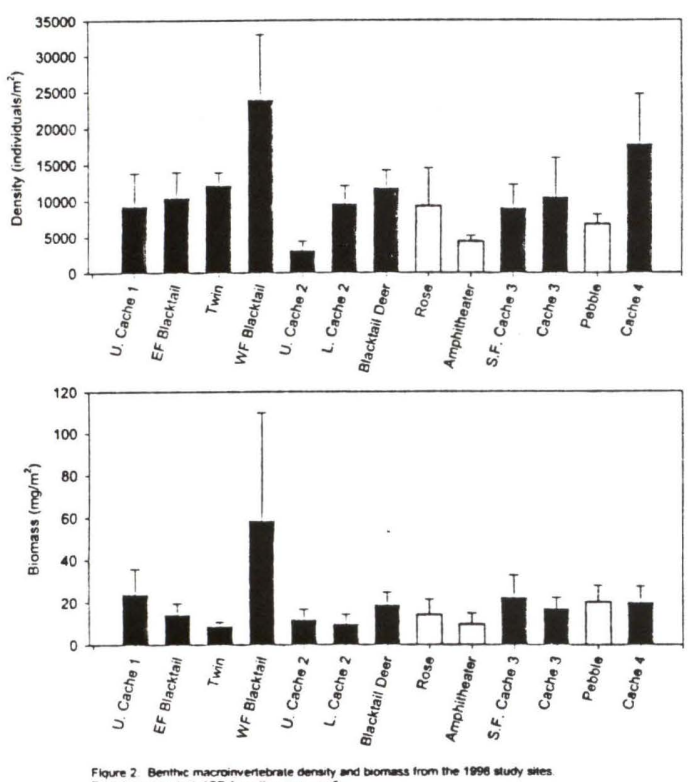

Mean taxa richness (number of taxa collected in the Surber sampler) was highest in Blacktail Deer with 50 taxa and lowest in Upper Cache 2 with 23 taxa (Figure 3). All of the Cache sites were similar to Amphitheater Creek which had 30 taxa. The Blacktail Deer sites as a group had higher taxa richness than the Cache Creek sites, (42-50 compared to 24-32 taxa) but were not significantly different from the reference streams. Simpson's Index was lowest in Pebble (0.09) and highest in Cache $3(0.34)$. The reference streams ranged from 0.09-0.17 indicating less diversity in the reference streams than in most of the burned streams, especially when comparing the $3^{\text {rd }}$ and $4^{\text {th }}$ order Cache streams with Pebble Creek.

Although WF Blacktail Deer had the highest mean invertebrate density, it had the lowest percent EPT of all the streams, $29+/-11 \%$ and the highest $\%$ Chironomidae $(42+/-8 \%)$ (Table 4$)$. Pebble had the highest $\%$ EPT, $78+/-35 \%$. \%EPT in the Cache streams were all lower than Amphitheater values. Although the Blacktail Deer sites had higher mean taxa richness than the Cache sites, the Cache sites had higher \%EPT (29$58 \%$ vs. $37-74 \%$ ). Rose, even though it had the lowest mean Simpson's Index and a high mean taxa richness, had only $55 \%$ EPT. The differences in densities and $\% \mathrm{EPT}$ in the burned compared to the reference streams were accompanied by an increase in the proportion of smaller, more vagile taxa, particularly Chironomidae and Baetis (Table 4).
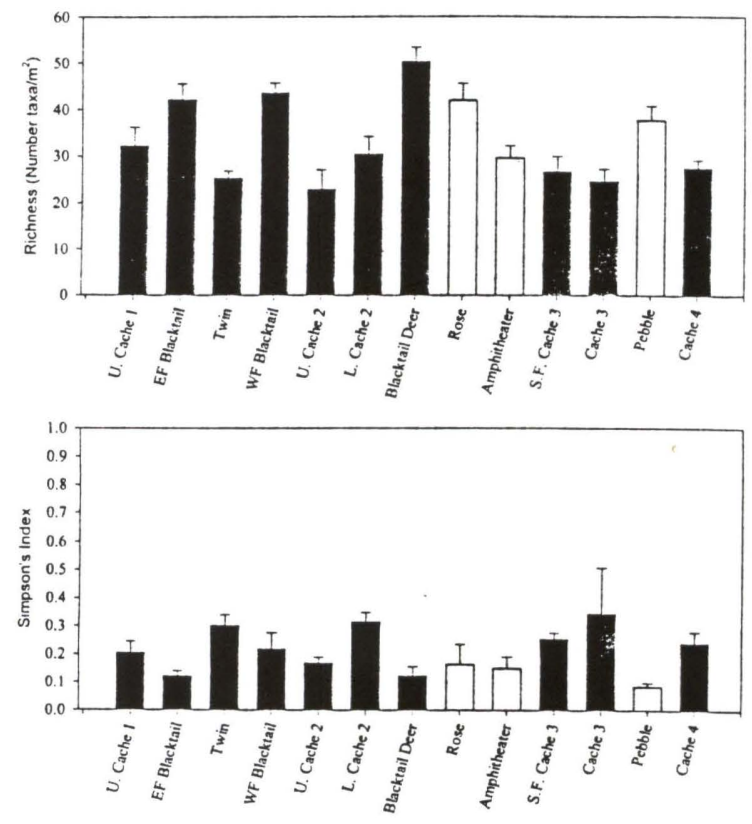

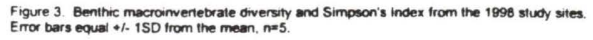

Table 4. Mean relative abundances of EPT. Baetis, and Chironomidae for the 1998 streams. SD= 1 standard deviation from the mean.

\begin{tabular}{lcccccc}
\hline \multicolumn{1}{c}{ Stream } & $\begin{array}{c}\text { Rel abund EPT } \\
\text { Mean (\%) }\end{array}$ & SD & $\begin{array}{c}\text { Rel abund Baetis } \\
\text { Mean }(\%)\end{array}$ & SD & $\begin{array}{c}\text { Rel abund Chir } \\
\text { Mean }(\%)\end{array}$ & SD \\
\cline { 2 - 7 } Upper Cache 1 & 37.0 & 22.0 & 0.9 & 0.8 & 4.0 & 4.4 \\
EF Blacktail Deer & 58.8 & 18.7 & 27.6 & 3.1 & 10.0 & 2.0 \\
TWin & 69.6 & 15.2 & 48.3 & 4.7 & 21.2 & 4.6 \\
WF Blacktail Deer & 29.1 & 10.6 & 10.8 & 1.7 & 41.6 & 8.3 \\
Upper Cache 2 & 56.0 & 24.0 & 2.0 & 1.6 & 2.8 & 3.6 \\
Lower Cache 2 & 64.0 & 23.0 & 48.0 & 2.0 & 9.0 & 1.0 \\
Main Blactail Deer & 35.4 & 23.2 & 26.0 & 4.3 & 16.0 & 86.3 \\
Rose & 55.2 & 54.1 & 15.7 & 15.2 & 34.5 & 36.3 \\
Amphitheater & 86.0 & 38.0 & 5.3 & 2.7 & 11.4 & 2.2 \\
SF Cache 3 & 84.0 & 21.0 & 50.0 & 5.0 & 23.0 & 5.0 \\
Cache 3 & 75.0 & 34.0 & 4.5 & 3.5 & 7.6 & 0.6 \\
Pebble & 77.5 & 34.9 & 15.5 & 4.7 & 9.8 & 1.8 \\
Cache 4 & 74.0 & 26.0 & 3.8 & 2.6 & 0.6 & 0.2 \\
\hline
\end{tabular}

\section{$\downarrow \quad$ DISCUSSION}

To summarize, chemical differences between streams were due to local geology and most likely not to the effects of fire. Burned third and fourth order streams were wider and shallower than third order unburned Pebble Creek while first and second order streams were similar in width and depth to Amphitheater and Rose Creeks. Although differences were not significant, mean percent substrate embeddedness was higher in the first and second order burned streams than the references streams; there was no difference in embeddedness between the third and 
fourth order burned streams and Pebble Creek. There was no apparent trend in periphyton chlorophyll $a$, periphyton AFDM or BOM values when comparing burned and reference streams. Benthic macroinvertebrate data, however, did indicate differences attributable to fire. In general, benthic macroinvertebrate densities were higher and \%EPT lower in the burned streams than in the reference streams. Also, Simpson's Index was lower in the reference streams than in all of the burned sites except Blacktail Deer (EF and main). These differences were accompanied by an increase in the proportion of smaller, more vagile taxa, suggesting a shift in community structure from $\mathrm{K}$ - to r-strategists. However, these differences did not exist for taxa richness or biomass, indicating that metabolic compensation accompanied the change in community structure. These results indicate that there still are discernable impacts on the macroinvertebrate community in these streams ten years after disturbance by wildfire. These results summarize only the findings of our 1998 studies and fire impacts are expected become even more apparent when trends over the whole ten years are examined (Minshall et al. in preparation).

Wildfire is a major large-scale disturbance that profoundly influences stream ecosystems over broad spatial and temporal scales. Past research has focused primarily on short-term effects, with most data collected within the first few months or years following wildfire, especially as related to changes in water chemistry. The present study took advantage of the unique opportunity to examine the midterm ( 10 year) recovery patterns in a set of streams affected by wildfire. Our research shows that substantial changes still are occurring in YNP streams ten years after disturbance by wildfire and documents the kind and extent of these changes. Very little is known about the longer-term effects of fire on streams, particularly from the broader perspective of major components of the entire ecosystem. Most of what is known about the ecological effects of wildfire after the first year is based on our 10-year study of the Mortar Creek Fire (MCF) (Minshall et al. 1999a,b) and our current 10-year study of the 1988 YNP Fires (see Minshall et al. 1997 for results from the first 5 years). Both of these studies have shown that dramatic changes take place during this 10 -year period but that a general recovery or improvement over immediate post-fire conditions may begin to occur within that time. However, it appears that substantial differences exist in the pattern and extent of recovery in these two systems. Initial impacts were less severe and short-term recovery faster in the YNP streams than those of the MCF; but, subsequent (mid-term) recovery seems to have been delayed or set back in the YNP streams as a result of increased precipitation, possibly associated with ENSO (El Nino Southern Oscillation, which includes La Nina) or global climate change. Therefore, it is important to document these events at relatively frequent intervals so that the patterns and rates of change can be determined. This makes our assessment, 5 years after the last full set of measurements and 10 years after wildfire, particularly important in terms of both basic science (role of fire in structuring stream ecosystems and their recovery from physical disturbance) and applied ecology (formulation of natural resource management policies).

\section{Literature Cited}

American Public Health Association. 1992. Standard methods for the examination of water and wastewater. APHA, New York.

Bovee, K.D. and R. Milhous. 1978. Hydraulic simulation in instream flow studies: theory and techniques. Instream flow information paper 5, U.S.F.W.S., Washington, D.C.

Lind, O.T. 1979. Handbook of common methods in limnology. $2^{\text {nd }}$ edition. C.V. Mosby Co., St. Louis. $199 \mathrm{pp}$.

Merritt, R.W. and K.W. Cummins (eds). 1996. An introduction to aquatic insects of North America. $3^{\text {rd }}$ edition. Kendall/Hunt Publishing Company, Dubuque, Iowa.

Mihuc, T.B., G.W. Minshall and C.T. Robinson.1996. Response of benthic macroinvertebrate populations in Cache Creek, Yellowstone National Park to the 1988 wildfires. Ecological Implications of Fire in Greater Yellowstone (Jason Greenlee ed.) 83-94.

Minshall, G.W., J.T. Brock, and J.D. Varley. 1989. Wildfires and Yellowstone's stream ecosystems: a temporal perspective shows that aquatic recovery parallels forest succession. BioScience 39: 707-715.

Minshall, G.W. and J.T. Brock. 1991. Observed and anticipated effects of forest fire on Yellowstone stream ecosystems. In B. Keiter and M.S. Boyce eds. The Greater Yellowstone Ecosystem: redefining America's wilderness heritage. Yale University Press. 
Minshall, G. W., J. T. Brock, D. A. Andrews, and C. T. Robinson. 1999a. Water quality, substratum, and biotic responses of five central Idaho (USA) streams during the first year following the Mortar Creek Fire. International Journal Wildland Fire, in press.

Minshall, G. W., C. T. Robinson, and D. E. Lawrence. 1997. Immediate and mid-term responses of lotic ecosystems in Yellowstone National Park, USA to wildfire. Canadian Journal Fisheries and Aquatic Sciences 54:2509-2525.

Minshall, G. W., C. T. Robinson, D.E. Lawrence, D. A. Andrews, and J. T. Brock). 1999b. Benthic macroinvertebrate assemblages in five Central Idaho (USA) streams over a 10-year period following disturbance by wildfire. International Journal of Wildland Fire, in press.

Platts, W.S., W.F. Megahan, and G.W. Minshall. 1983. Methods for evaluating stream, riparian, and biotic conditions. U.S. Forest Service General technical Report INT-138. $70 \mathrm{pp}$.
Robinson, C.T. and G.W. Minshall. 1996. Physical and chemical responses of streams in Yellowstone National Park following the 1988 wildfires. Ecological Implications of Fire in Greater Yellowstone (Jason Greenlee ed.) 217-221.

Strahler, A.N. 1952. Hypsometric (area-altitude) analysis of erosional topograph. Bull. Geol. Soc. Am. 63: 1117-1142.

Tiedemann, A.R., C.E. Conrad, J.H. Dieterich, J.W.Hornbeck, W.F. Megahan, L.A. Viereck, and D.D. Wade. 1979. Effects of fire on water: A state-of-knowledge review. USFS General Technical Report WO-10.

Weber, C.I. (Ed.) 1973. Biological field and laboratory methods for measuring the quality of surface waters and effluents. EPA-670/473-001 U.S. EPA, Cincinnati. 53 p. 